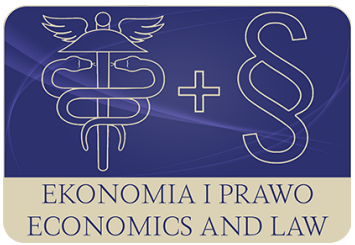

EKONOMIA I PRAWO. ECONOMICS AND LAW

Volume 15, Issue 3, September 2016

p-ISSN 1898-2255, e-ISSN 2392-1625

www.economicsandlaw.pl

ORIGINAL ARTICLE

received 23.07.2015; revised 21.06.2016; accepted 30.09.2016

Citation: Moszyński, M. (2016). Institutional conditioning of the German labour market in the face of the global economic crisis 2008-2009. Ekonomia i Prawo. Ecomomics and Law, 15(3): 371-383.

doi:10.12775/EiP.2016.025.

\title{
Institutional conditioning of the German labour market in the face of the global economic crisis 2008-2009
}

\begin{abstract}
MICHAE MOSZYŃSKI
Nicolaus Copernicus University, Faculty of Economics and Management, Department of Economics, ul. Gagarina 13A, 87-100 Toruń, Poland
\end{abstract}

曰moszyn@umk.pl

\begin{abstract}
Aim: The scientific objective of this study is an attempt to clarify the institutional aspects of the functioning of the labour market in Germany that are relevant to the response to the global economic crisis of 2008-2009.

Motivation: The reaction of German labour market was totally different than during previous recessions and the explanation of the sources of this response constitutes the main motivation to undertake this study. The considerations rely on the thesis that it could be attributed to the institutional infrastructure combined with clever economic policy of the state and responsible behaviour of social partners. The economic theory suggests how an isolated institution functions, but in the real world they works in the whole insti-

tutional network. Therefore the broader context and some linkages are mentioned.

Results: After a brief review of the main macroeconomic indicators and selected labour market institutions in Germany in comparison to the OECD countries, the labour market reforms undertaken in the period between 2002 and 2007 will be discussed. Then, selected on the basis of literature studies, institutional buffers of the labour market mitigating shocks are examined with particular emphasis on the instruments of internal flexibility, social partners' behaviour and institutional connections of labour markets with other domains of economic order. The elements of institutional framework are subject to qualitative analysis backed up by available official statistical data.
\end{abstract}

Keywords: crisis; Germany; labour market institutions; employment; unemployment JEL: E24; H12; J52; Al1; Al4; B16 


\section{Introduction}

The unemployment rate in Germany after reaching a peak of $12.1 \%$ in 2005 began to decline steadily, and the improvement of the situation on the labour market followed even in the face of the global economic crisis after 2007. These positive trends, especially in comparison with other EU countries, draw attention and are discussed in the literature. Naturally, the situation on the labour market largely depends on the overall macroeconomic background before the crisis, and in Germany in the spring of 2008 it was very good: unemployment was continuing to decline, employment was growing (chart 1), a consolidation of public finances took place and since the autumn of 2008 the economy was supported by low interest rates, and the main problem was the lack of qualified personnel.

Secondly, an active employment and the labour market policy is praised in the face of the crisis. Last but not least, the institutional aspects of the German labour market are emphasized. A very different reaction of the labour markets of the developed countries to the crisis of 2008-2009 suggests that it is worth doing a deeper analysis of their institutional conditions. Due to their specificity, labour markets constitute an area of special regulation, imbued with formal and informal institutions that determine their function (Balcerzak, 2009a, pp. 100-101; 2009b, pp. 75-88). Institutional framework of the labour market in Germany has been thoroughly reformed since 2002, which affected the way of reacting to the shock caused by the crisis - other than usual in Germany and different from most developed countries. An attempt to explain these conditions is a research objective of the study.

\section{Current state of knowledge - labour market institutions 'matter', but how?}

As indicated by Blanchard and Wolfers (2000), labour market institutions have an impact on how employment and unemployment react to negative shocks. For example, a better coordination in the wage bargaining may lead to faster adjustments in real wages relative to productivity growth slowdown. According to this approach, institutional differences illustrate different reactions of the labour markets to shocks.

Comparing the data on GDP decline in the first quarters of the crisis (2009/2009) and the increase in the unemployment rate in OECD countries, we do not notice any discernible pattern. For example, Spain experienced less than an average decline in GDP, however the unemployment reacted very strongly, while in Germany the decline in GDP was sharp, but the unemployment rose the least. This indicates clearly how differently labour markets reacted to the negative shock. These differences can be largely explained by a diverse configuration of labour market institutions. 
It is claimed that the German labour market shows a relative level of rigidity, even taking into account the wave of deregulation and reforms (Balcerzak \& Rogalska, 2009, pp. 40-48). This view can be based on a theoretical analysis of how labour market institutions - considered in isolation - have impact on the state of equilibrium level of employment on the labour market. This is illustrated by the data in table 1 - the higher the expected level of employment, the higher the rank. For example, high protection against dismissal ranked Germany in 26th place, while the ratio of minimum wage to the median wage (before the introduction of the national minimum wage) - in first place. The average of the first six indicators presented in the table 1 has placed Germany in 18th place in the group of 27 developed countries.

According to the presented indicators when the crisis erupted in 2008, German labour market institutions did not allow to expect good employment results. This shows that their connection plays an important part; similarly, the institutional ties of the labour market play such a role — with other domains of economic life in the economic order as a whole, such as social security systems, taxation and education.

\section{The methodology of research}

For the purpose of the chosen research problem the most appropriate method is an institutional analysis. It allows to consider the organisational framework of the labour market in the wider context. The totally different reaction of the German labour market to the exogenous shock in comparison to the previous recessions suggest the crucial role of the changed institutional environment. Thus, the reforms and their effects were shortly described. In the paper the labour market institutions in Germany are examined, selected on the basis of literature studies. The elements of institutional framework are subject to qualitative analysis backed up by available official statistical data. The results are good starting point for more detailed numerical examination.

\section{The research process}

The analysis starts with the labour markets reforms changing the institutional framework and working incentives. It will then focus on following areas: instruments of within-firm flexibility implemented to maintain the stable employment, the behavior of social partners and, finally, dual educational system.

\subsection{Labour market reforms before the crisis and their effects}

The reforms have improved the efficiency of labour market institutions in terms of creating new jobs, both those affecting the supply side and the corporate sector. 
In the case of employees they strengthened the incentives to take up employment and participation in the labour market, especially for a low-wage segment. The replacement rates and reservation wage were lowered (Arent \& Nagl, 2001). According to the OECD statistics, it lowered the NAIRU, which in 2005 was at $8.1 \%$ and in 2010 only at $7.1 \%$. Changes in the structure of incentives require that a labour market links with the social security system and tax system are taken into account. These relationships are mutually reinforcing - if the situation on the labour market improves, tax revenue grows and social security systems are supported. This also works the other way round - reducing taxes and non-wage labour costs encourages to take up jobs and create jobs.

The second aspect of the reforms is to improve the matching efficiency, which is reflected by the inward Beveridge curve shift. In the period 20072009 both the unemployment rate and the rate of job vacancies fell. This can be mainly attributed to the Hartz I-III reforms which, among others, abolished the job placement monopoly of the Federal Employment Agency.

The created incentives for longer working life clearly increased the employment rate of older workers, and - unlike during previous recessions - reduced the unemployment rate. Between 2007 and 2014, the employment rate in the age group of 55-64-year-olds gradually grew from $51.3 \%$ to $65.6 \%$ and clearly exceeded the OECD average. Accordingly, the activity rate also increased from 57.2 to $69.1 \%$. The measures have succeeded in bringing down the long-term unemployment, a traditional problem group on the German labour market. In 2007 the unemployed who stayed without a job for over a year accounted for almost $57 \%$ of the total, and this share began to gently fall to $44.3 \%$ in 2014 .

The reforms have improved the situation of enterprises which could better than ever before surround their most valuable employees, carriers of human capital, with security buffer (table 2). This buffer includes instruments enhancing the internal and external flexibility. External flexibility is achieved through the instruments used in the enterprise in order to adapt headcount to their actual needs (quantitative flexibility), mainly through hiring and firing, but also by various forms of atypical forms of employment such as fixed-term or temporary work. The non-renewal of fixed-term employment is a typical strategy to protect the key regular workers. In Germany the group most affected by the crisis were temporary agency workers, because in the period 30/09/2008-03/09/2009 their employment decreased by about $20 \%$; by contrast, employment in the industry decreased by only about $4 \%$.

In the face of the crisis in Germany the internal flexibility played a more important role. It is based mainly on adapting the volume of work to production requirements by adjusting the working time of employees. It is also based on balancing the organization of work and work qualifications. In contrast to the external flexibility it does not need to affect the number of employees. External and internal flexibility can complement, as well as substitute each other. The necessity of the quantitative adjustment of employment to changes in demand for products and services the company is conditioned, among other things, by 
wage rigidity. In Germany, wages are largely determined by the tariff systems and are difficult to quickly change at the company level. Besides, a constant wage adjustment to changing conditions is not very convenient for the firm. The inflexibility of wages encourages the use of overtime and short-time work, the firing and hiring of staff, as well as the use of various forms of short-term employment.

\subsection{Internal flexibility - working time control}

The instruments used by the companies based on the reduction of working time included two main groups of tools: use of working time accounts and the use of subsidies to employment in the form of so-called short-work (Kurzarbeit).

Working time accounts enable better working hour management in the periods of fluctuations in demand. To mitigate the effects of fluctuations best suited are the models that allow the accumulation and spending of surplus time in the long run, e.g. a year. The popularity of this instrument is growing, as in $199935 \%$ of the workforce had such account and in 2009 already $51 \%$. In 2009 in the EU27 38\% of establishments with 10 or more employees used some form of flexitime scheme with possibility of taking free time, in Germany it was about 52\% (Eurofound, 2009, p. 7). The research on work councils (workforce representation), conducted twice by Wirtschafts- und Sozialwissenschaftliches Institut (Fall 2009 and Spring 2010), indicates that exactly one-third of enterprises made use of the time accounts in order to secure employment (Zapf \& Herzog-Stein, 2011). Companies entered the crisis with full accounts, which naturally created an opportunity to spend the accumulated hours and compensate for the time off, and even to enter the negative zone. In Germany the instrument is used primarily by industrial companies (almost a half of them) and, to a lesser extent, the service ones (approx. 25\%). The accumulation time limits are higher in the industry. The collapse of industrial production during the crisis was stronger than in the services, which indirectly proves that this instrument was widely used to protect jobs (Zapf \& Herzog-Stein, 2011).

Short work allows an employer to lower time and labour costs and creates an alternative to layoffs during the inevitable short-term adjustments in the economy. Working hours can be reduced up to $100 \%$, and this solution compensates employees for the loss of $60 \%$ of net wages lost due to the time reduction. The employer receives funds from the Federal Employment Agency. Social Insurance Contributions are usually paid by the employer and employee in half; in this case they are fully taken over by the employer. During the crisis, half of the employer's contribution was paid by the Agency. Normally the permit for an introduction of this instrument due to the cyclical reasons is obtained for 6 months, but during the crisis this period was prolonged up to 24 months. The use of the instrument is flexible for the company, but it must include a minimum of one-third of the crew, for a minimum of 4 weeks with a minimum of $10 \%$ reduction in working time (this requirement was suspended from 2009 
to 2011). The instrument can be used when all standard measures such as reduction of overtime, leave, transfer of workers to other parts of the company have been exhausted. Furthermore, the implementation of work summary must be approved by a works council, due to the fact that changes in working conditions must be co-decided. The council may also request the implementation of the short work and in case of an employer's refusal; call the arbitrator (Einigungsstelle). One of the functions of works councils is to take measures aimed at avoiding layoffs. In small companies or in situations where there is no works council, short work as the change in working conditions must be accepted by individual employees.

The number of employed in the system of short work had increased sharply and in 2009 on average amounted to more than a million. In their case work time shortened on average by one third, which in terms of all employees amounted to 15.5 hours (compared to 1.8 in 2008). The reserves on time accounts fell by more than 9 hours and the number of overtime hours by 13. In 2009 the number of people employed part-time also increased by 220 thousand (1.8\%), while full time posts were reduced by approximately 240 thousand (1\%). The volume of working time in the economy fell by $2.9 \%$ and this was mainly caused by the reduction of working time (rather than a reduction in the number of posts). All this demonstrates the wide range of measures relating to working time used to secure employment.

In 2007-2009, the reduction of annual working time was on average almost 45 hours on the jobholder, almost 19 hours of which was due to the change of tariff or company working time, and on a smaller scale due to the short work, reduction of overtime and time accounts (Herzog-Stein \& Seifert, 2010, p. 555). In the period from 2000 to 2009 the annual working hours per employee fell from 1387 to 1309 hours, or by 6\%, most of which in just 2009 alone. The decrease in labour utilization meant that productivity per hour decreased, providing some reserve capacity for the incoming recovery.

According to the Institute of Employment Research in Nürnberg, average annual working time in 2009 fell by 3.2\% because of short work and the use of temporary accounts (Instituts für Arbeitsmarkt- und Berufsforschung, 2010). This decrease corresponds arithmetically to the 1.2 million jobs that have been preserved. The other researchers' analyses, covering the period from 2008 to June 2009, confirm the effectiveness of the instrument (Boeri \& Brücker, 2011, pp. 697-765). The extension of the period of analyses by a year does not bring such clear results for the changes in employment levels to differ significantly between companies applying and not applying the short work (Kruppe \& Scholz, 2014). This means that the effectiveness of the instrument in the employment protection may not be as high as it is supposed to be. Similar conclusions were reached by M. Burda and J. Hunt (2011, pp. 273-335), who argue that the reduction of working time from 2008 to 2009 substituted for traditional government-sponsored short-time work. 
The instrument is effective in a particular context. In the case of the analysed crisis it is indisputable that the recession affected mostly export-oriented sectors, especially the industry. Germany, unlike the other developed countries, has preserved its industrial base almost unchanged (in terms of contribution to GDP), this sector has for long suffered from a shortage of highly qualified specialists, thus was particularly interested in keeping them (labour hoarding). This explains a high popularity of short work - in mid-2009 the industry employed 4/5 of all workers covered by this instrument.

To summarize the effects of reduced working time during the crisis, one should conclude that they allow, at least in the short term, to secure jobs. Subsidized employment and emptying time accounts, is much more beneficial on a macro scale than lay-offs due to the stabilization of household income. Therefore, short work and time accounts can be regarded as automatic stabilizers, protecting other workers as well, in the economy through stabilizing aggregated demand.

\subsection{The behaviour of the social partners - informal pact for employment}

Since 1998 government and social partners (trade unions and employers' organisations) have been conducting regular talks in the framework of the tripartite pact for work (Bündnis für Arbeit, Ausbildung und Wettbewerbsfähigkeit). Their aim was to improve the institutional framework of the labour market, including the issues of vocational training, working hours flexibilisation, reduction of overtime, the introduction of Kombilohn (subsidized jobs in the low-wage sector) etc. The pact collapsed in the spring of 2003 due to the insurmountable differences between the unions and employers' organizations.

After 2000 the employers' organizations have been more active and demanded an extension of working time and other arrangements to their benefit. From 2002 to 2003 the recession initiated the discussion on a more flexible tariff systems. While in some industries the opt out clauses in collective agreement allowing different solutions (Öffnungsklauseln) gave some leeway to individual firms, in other industries derogation from the regional collective agreement (Flächentarifvertrag) were permitted only in exceptional economic circumstances. It turned out that the minimum standards imposed on the industry as a whole constitute a bottleneck, leading to the erosion of bargaining coverage. Many firms prefer to stay out of agreements, but still use them as a benchmark in wage bargaining process. In 2003 Chancellor Schröder (2003) threatened the tariff partners that if they do not make the tariff systems more flexible in order to give the opportunity to implement solutions at the company level, the legislature will enter. In response to this threat in the metal industry, electricity, and later in others industries, opening clauses have been introduced, not only in crisis situations. 
For Germany, basing its growth on export, international competitiveness is crucial, and its primary indicators are unit labour costs. In the pre-crisis period from 2003 to 2007, these costs were falling, while e.g. in the United States, France and Britain they were growing. Labour costs in the period from 2000 to 2009 increased by $15.7 \%$, labour productivity by $8.1 \%$, while nominal unit labour costs by $7 \%$, and in real terms (adjusted by the GDP deflator) - fell by $3.8 \%$ (Lesch, 2010, p. 3). This phenomenon has caused a number of positive consequences: increased international competitiveness and low pressure on prices allowed for low nominal interest rates, which in turn sustained aggregate demand. The decline in real labour costs stimulated demand for labour and the volume of working time.

The decline in unit labour costs can, to a large extent, be attributed to the behaviour of social partners. The German model of industrial relations is based on cooperation between employers' organizations and trade unions, and at a company level - their cooperation with works councils. This does not eliminate, of course, collective labour disputes, but unlike in the other developed countries, the relationships are more consensual and less confrontational (Dustmann et al., 2014, p. 177). Trade unions have demonstrated an exceptional level of discipline when it comes to wage demands, and the bargaining process resulted in relatively moderate wage growth. In turn, employers saved the jobs in spite of low capacity utilization. The state helped by subsidizing the jobs more generously than usual within the short work and by maintaining stable social security contributions level. Thanks to the coordinated actions it has succeeded to 'fire the hours, not the workers' as the chief of IG-Metall union stated (Huber, 2009, p. 12).

\subsection{Institutional linking of the labour market with other domains of economic order - an example of dual educational system}

For a developed country, Germany shows an exceptionally low youth unemployment rate. Although it increased slightly (to $11.3 \%$ ) in 2009, the downward trend has been maintained and in 2014 the unemployment rate in the age group of 15 to 24 was $7.8 \%$, while in the entire OECD almost twice as high. By contrast, in Spain the rate in 2007 was 18\%, while in 2012 more than 50\%.

Germany's success is attributed to the dual system of education, which is an interesting institutional solution to facilitate the transition between vocational education and real professional life. This solution is the result of a long evolution initiated already in the nineteenth century by enterprises and formally implemented into legislation in 1922 (Neumann, 2010, p. 56). The system involves the business sector in the education system, demand a financially support from companies, but allows to equip young people with the skills needed by the industry. Moreover, the system is backed by the Federal Institute for Vocational Education and Training (Bundesinstitut für Berufsbildung), which conducts research and development, provides services and advice. Although the number 
of participants in the system decreases in the long run and it requires to be reformed, its idea generally works and still serves its purpose.

\section{The results of research}

The reforms undertaken by Germany in 2002 changed the institutional infrastructure and prepared the labour market for the crisis. What has been improved? First of all, the structure of incentives to take up and maintain employment and to provide the firms with the tools of internal and external flexibility. Within these interrelated institutions, labour market actors - enterprises and employees and their representations - could (and wanted to), with the support of the state, withstand the most severe recession in decades. The crisis confirmed the intact social partnership as a prior condition for tackling the problems of absorbing the enormous shock in GDP. Before and during the crisis the workers and their representatives were ready to accept lower wages and to reduce the working time which helped to avoid redundancies. The government did not hesitate to use short time work - an 'old' labour market policy instrument - which has been temporary tuned up to the exceptional conditions.

\section{Conclusion}

The growing convergence among the developed countries in terms of the relationship between production and employment (Okun's law) observed since the 70s has collapsed (Daly et al., 2013). The emerging differences among economies in the face of crisis are a very general measure, which indicates that institutional and industrial relations 'matter' for the capacity to absorb shocks and for a short-term and long-term growth path. For the science it is a challenge not only to analyse individual institutions but to capture their interactions and to explore their relationship to other elements of the economic order.

The German labour market during the Great Recession proves that the direction of change of the labour market institutions chosen at the beginning of the 2000s was accurate and should be continued. In this context, the introduction of the minimum wage at the beginning of 2015 should be seen as contradictory to the logic of up-to-date practice, given that the German labour market will still face many challenges such as long-term unemployment, improving opportunities for employment of the low-skilled or inclusion of the waves of immigrants. This will require further deliberate (re)constructing of institutions. What is important: the institutions must be flexible and give the government the room for manoeuvre, as in the case of Kurzarbeit.

The German example shows that intersystemic competition can be a source of learning for other countries, which is particularly important for the Eurozone and the success of European integration. Although efficient copying of institutions - due to their interdependence - is not a simple matter, but there should 
be attempts to adapt some solutions such as linking the education system more closely with the work practice as in the model of dual educational system.

\section{References}

Arent, S., \& Nagl, W. (2001). Unemployment Benefit and Wages: The Impact of the Labor Market Reform in Germany on (Reservation) Wages. Ifo Working Paper, 101.

Balcerzak, A.P. (2009a). Wpływ działalności regulacyjnej państwa w obszarze kreowania ładu konkurencyjnego na rozwój nowej gospodarki. In A.P. Balcerzak, \& M. Moszyński (Eds.). Aktywność regulacyjna państwa a potencjat rozwojowy gospodarki. Toruń: Polskie Towarzystwo Ekonomiczne Oddział w Toruniu.

Balcerzak, A.P. (Ed.). (2009b). Polski rynek pracy w warunkach integracji europejskiej. Toruń: Wydawnictwo Adam Marszałek.

Balcerzak, A.P., \& Rogalska, E. (2009). Effectiveness of Polish Labour Market: Taxonometric Analysis of European Union Countries in the Years 20042007. Research Papers of Wroctaw University of Economics - Global Challenges and Policies of the European Union - Consequences for the 'New Member States', 59.

Blanchard, O., \& Wolfers, J. (2000). The role of shocks and institutions in the rise of European unemployment: the aggregate evidence. The Economic Journal, 110(462). doi:10.1111/1468-0297.00518.

Boeri, T., \& Brücker, H. (2011). Short-time work benefits revisited: some lessons from the Great Recession. Economic Policy, 26(68). doi:10.1111/j.1468-0327.2011.271.x.

Burda, M.C., \& Hunt, J. (2011). What Explains the German Labour Market, Miracle in the Great Recession? Brookings Papers on Economic Activity, 1.

Daly, M.C., Fernald, J., Jorda, O., \& Nechio F. (2013). Labor Markets in the Global Financial Crisis. FRBSF Economic Letter, 38.

Dustmann, C., Fitzenberger, B., Schönberg U., \& Spitz-Oener A. (2014). From the Sick Man of Europe to Economic Superstar. Journal of Economic Perspectives, 28(1). doi:10.1257/jep.28.1.167.

Eurofound (2009). European Company Survey 2009. Retrieved 12.05.2014 from http://www.eurofound.europa.eu.

Herzog-Stein, A., \& Seifert, H. (2010). Der Arbeitsmarkt in der Großen Rezession - Bewährte Strategien in neuen Formen. WSI Mitteilungen, 11.

Huber, B. (2009). Zukunft der Gewerkschaften - Zukunft der Arbeitsgesellschaft. In Friedrich-Ebert-Stiftung (Ed.), Zukunft der Gewerkschaften-Zukunft der Arbeitsgesellschaft. Bonn: Bonner Dialog.

Hüfner, F., \& Klein, C. (2012). The German Labour Market Preparing for the Future. OECD Economics Department Working Papers, 983. doi:10.1787/5k92sn0ltzzv-en. 
Instituts für Arbeitsmarkt- und Berufsforschung (2010), Retrieved 12.05.2014 from www.iab.de.

Kruppe, T., \& Scholz, T. (2014). Labour hoarding in Germany Employment effects of short-time work during the crises. IAB-Discussion Paper, 17.

Lesch, H. (2010). Lohnpolitik 2000 bis 2009 - Ein informelles Bündnis für Arbeit. IW-Trends, 1.

Neumann, K.T. (2010). Einsatz für die Zukunft. Handelsblatt, 12.05.2014.

Rinne, U., \& Zimmermann, K.F. (2012). Another Economic Miracle? The German Labor Market and the Great Recession. IZA Journal of Labor Policy, 1(3). doi:10.1186/2193-9004-1-3.

Sachverständigenrat zur Begutachtung der gesamtwirtschaftlichen Entwicklung (2013). Jahresgutachten 2013/14, Retrieved 12.05.2014 from https:// www.sachverstaendigenrat-wirtschaft.de.

Schröder, G. (2003). Regierungserklärung vor dem Deutschen Bundestag am 14. März 2003. Mut zum Frieden und Mut zur Veränderung. Bulletin der Bundesregierung, 21-1, 14.03.2003.

Zapf, I., \& Herzog-Stein, A. (2011). Betriebliche Einsatzmuster von Arbeitszeitkonten während der Großen Rezession. WSI-Mitteilungen, 2.

\section{Acknowledgements}

Author contributions: author have given approval to the final version of the article.

Funding: this research was fully funded by the statutory sources. 


\section{Appendix}

Table 1.

Institutional labour market indicators in 2008 — the position of Germany in the group of 27 OECD countries

\begin{tabular}{ccccccccc}
\hline Index & A & B & C & D & E & F & G & H \\
\hline Position & 26 & 10 & 18 & 1 & 14 & 26 & 19 & 27 \\
\hline
\end{tabular}

A: protection against dismissals (OECD EPRC-index); B: the share of temporary employment in total employment; C: replacement rate; D: the ratio of minimum wage to the median wage; E: bargaining coverage; F: tax wedge; G: subindex 'labour market efficiency' of the World Economic Forum CGI index; H: Index of labour market regulation by Fraser Institute.

Source: Sachverständigenrat zur Begutachtung der gesamtwirtschaftlichen Entwicklung (2013, p. 258).

Table 2.

Labour market reforms in Germany in 2002-2007

\begin{tabular}{|c|c|c|}
\hline Reform/Date & Main measures & Likely effect \\
\hline $\begin{array}{c}\text { Job-AQTIVE Law } \\
1.01 .2002\end{array}$ & $\begin{array}{l}\text { Training: changes in benefit claims during and after partici- } \\
\text { pation; } \\
\text { Job placement: profiling, aptitude tests, assignment of third } \\
\text { parties; } \\
\text { Compulsory registration for those threatened with unemploy- } \\
\text { ment; } \\
\text { Changes in responsibility of job offers. }\end{array}$ & $\begin{array}{l}\text { Improved job search } \\
\text { efficiency }\end{array}$ \\
\hline $\begin{array}{l}\text { Hartz I/II } \\
1.01 .2003\end{array}$ & $\begin{array}{l}\text { Training: introduction of voucher, stricter selection criteria; } \\
\text { Deregulation of temporary employment; } \\
\text { Cut in unemployment assistance; } \\
\text { Compulsory registration as job seeker at the time of layoff } \\
\text { notification; } \\
\text { Further changes in reasonability of job offers; } \\
\text { Tightening of rules for exclusion from benefits. }\end{array}$ & $\begin{array}{l}\text { Improved job search } \\
\text { efficiency; } \\
\text { Raising incentives for } \\
\text { taking up employment }\end{array}$ \\
\hline $\begin{array}{l}\text { Hartz III } \\
1.01 .2004\end{array}$ & $\begin{array}{l}\text { Reorganization of the Federal Labour Agency; } \\
\text { Legislative changes concerning job creation schemes; } \\
\text { Alteration of unemployment benefit legislation; } \\
\text { Further tightening of rules for exclusion from benefits. }\end{array}$ & $\begin{array}{l}\text { Improved job search } \\
\text { efficiency }\end{array}$ \\
\hline $\begin{array}{l}\text { Hartz IV } \\
1.01 .2005\end{array}$ & $\begin{array}{l}\text { Combination of unemployment assistance and social assistance } \\
\text { into new means-tested unemployment benefit system; } \\
\text { Introduction of One-Euro-Jobs. }\end{array}$ & $\begin{array}{l}\text { Raising work incentives for } \\
\text { welfare recipients }\end{array}$ \\
\hline $\begin{array}{l}02.2006 \\
10.2006 \\
05.2007\end{array}$ & $\begin{array}{l}\text { Shortening unemployment benefit duration for older workers. } \\
\text { Phasing out of early retirement options. } \\
\text { Law to Improve Employment Opportunities for Older People. }\end{array}$ & $\begin{array}{l}\text { Increase work incentives } \\
\text { for older workers }\end{array}$ \\
\hline
\end{tabular}

Source: own elaboration based on Hüfner \& Klein (2012), Rinne \& Zimmermann (2012). 


\section{Chart 1.}

Employment and unemployment in Germany in the 1999-2015 (in millions)

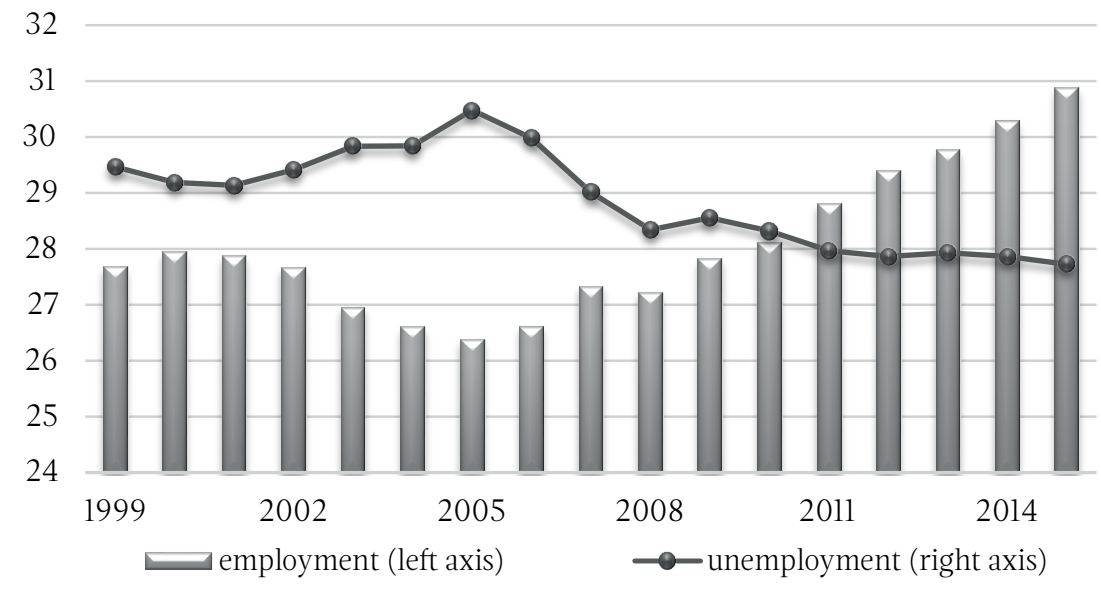

Source: own preparation based on data of Federal Employment Agency. 
